\title{
ANALISIS PREFERENSI KONSUMEN DALAM MEMBELI DAGING BROILER DI PASAR TRADISIONAL KOTA MANADO (STUDI KASUS "PASAR PINASUNGKULAN KAROMBASAN")
}

\author{
Lasmaria Simarmata, R.E.M.F.Osak*,E.K.M. Endoh, Franky N. S. Oroh \\ Fakultas Peternakan, Universitas Sam Ratulangi Manado, 95115
}

\begin{abstract}
ABSTRAK
Penelitian ini dilakukan untuk menganalisis perbedaan preferensi konsumen membeli ayam pedaging dan sikap konsumen terhadap atribut daging broiler di pasar tradisional kota Manado. Penelitian dilakukan di pasar Pinasungkulan Karombasan Manado pada Februari 2019. Metode penelitian menggunakan metode survei dengan wawancara berdasarkan daftar pertanyaan pada kuesioner. Sampel ditentukan dengan metode accidental sampling dengan 50 orang sampel. Sumber data yang digunakan adalah data primer dan sekunder dengan analisis ChiSquare dan Multi atribut Fishbein. Analisis Chi-Square menunjukkan bahwa semua atribut yang diteliti berbeda nyata dengan tarf kepercayaan 95\%. Berarti ada perbedaan preferensi konsumen pada ayam pedaging. Berdasarkan analisis Multiatribut Fishbein menunjukkan bahwa semua atribut daging broiler dipertimbangkan oleh konsumen dalam membuat keputusan untuk membeli daging broiler yang menjadi preferensi konsumen secara nyata di Pasar Pinasungkulan,. Urutan atribut ayam pedaging dari pertimbangan tertinggi sampai ke pertimbangan terendah adalah warna daging, warna kulit, bau daging, kelembutan kulit dan berat daging.
\end{abstract}

Kata kunci: Daging broiler, Preferensi konsumen

\footnotetext{
*Korespondensi (corresponding aouthor): Email: richard_osak@yahoo.com
}

\begin{abstract}
ANALYSIS OF CONSUMER BUYING PREFERENCES IN BROILER MEAT AT TRADITIONAL MARKET IN MANADO CITY (CASE STUDY OF THE "PINASUNGKULAN KAROMBASAN MARKET"). The goals of this study was to analyze consumer preference and attitude on attribute variation of broilers at the traditional market in Manado. Study was conducted at the Pinasungkulan market, Karombasan Manado on February 2019. Survey method was used by deep interview supported by questionnaire. Samples were defined by accidental sampling method involving fifty respondents. The primer and secondary data were used in this study and analyzed by Chi-Square and Multi attribute Fishbein analysis. The Chi-Square analysis indicated that all attributes studied were significantly different. This was meaning that there were differences of consumers preference on broilers. On the basis of Multi attribute Fishbein analysis indicated that all broiler attribute were considered by consumers in making decision of buying broilers. Broilers were became consumer preference significantly at the Pinasungkulan Market, meaning that there was difference of consumer preference on broiler attributes. Sequences of broiler attribute from the highest consideration to the lowest consideration were meat color, skin color, meat smell, skin tenderness and meat weight. Consumer attitude on broiler meat attributed in decision of buying meat of broilers was broiler meat color.
\end{abstract}


Keywords: Broiler, consumer preference

\section{PENDAHULUAN}

Daging broiler adalah suatubahan makanan yang mengandung gizi tinggi memiliki rasa dan aroma yang enak, tekstur yang lunak dan harga yang relative murah, sehingga hampir disukai semua orang (Suradi, 2006). Atribut yang terdapat dalam daging broiler meliputi kesegaran, aroma, ketersediaan, tekstur, ukuran dan harga. Atribu ttersebut dapat dipertimbangkan oleh konsumen dalam mengambil keputusan tentang pembelian daging ayam broiler.

Menurut Majid (2008), pasar tradisional adalah tempat pembeli dan penjual melakukan transaksi secara langsung dan disertai dengan proses tawar-menawar. Konsumen yang semakin selektif dalam menentukan pilihan saat membeli daging broiler, salah satu pemikiran bagi para produsen dalam upaya memaksimalkan kepuasan pelanggan. Pemilihan atribut berkaitan dengan tingkat kepentingan dan kesesuaian produk yang dianggap dapat memuaskan keinginan konsumen. Pemahaman terhadap atribut yang menjadi pilihan konsumen akan memudahkan para produsen untuk memberikan perhatian lebih terhadap atribut tersebut, sehingga dapat mengubah dan membentuk sikap konsumen lebih positif terhadap daging broiler. Kepuasan pelanggan adalah tingkat perasaan pelanggan setelah membandingkan nilai atribut produk dengan harapannya terhadap nilai atribut produk tersebut. Seorang pelanggan yang memiliki sikap merasa puas terhadap nilai yang diberikan oleh suatu produk, kemungkinan besar menjadi pelanggan dalam waktu yang lama, dan kepuasan pelanggan berpengaruh terhadap angka penjualan yang akhirnya memberikan keuntungan kepada pedagang daging broiler. Sikap merupakan suatu penilaian konsumen terhadap atribut dari suatu objek. Kemampuan konsumen yang berbeda dalam menyebutkan karakteristik adalah tujuan konsumen untuk memuaskan suatu kebutuhan dengan mencari fungsi dari atribut produk.

Produsen perlu mengetahui selera konsumen dalam menentukan pilihan suka atau tidak suka seorang konsumen terhadap suatu produk. Konsumen mendasarkan harapannya kepada informasi yang mereka terima tentang produk dan memperhatikan serta mempertimbangkan ciri-ciri fisik (atribut) produk sebelum membeli. Jika kenyataan yang mereka dapat ternyata berbeda dengan yang diharapkan maka mereka tidak puas. Namun, apabila produk tersebut memenuhi harapan, mereka akan merasa puas. Dalam hal ini atribut produk menjadi hal yang sangat penting untuk dipertimbangkan oleh konsumen sebelum membeli sebuah produk. 
Begitu juga dalam pembelian daging broiler, beberapa atribut menjadi pertimbangan konsumen antara lain adalah bobot, warna daging, warna kulit, kekenyalan daging, baudaging dan kebersihandaging broiler.

Perilaku konsumen adalah tindakan yang langsung terlibat dalam mendapatkan, mengkonsumsi dan menghabiskan produk dan jasa termasuk proses keputusan yang mendahului dan menyusuli tindakan (Setiadi,2003). Faktor-faktor yang mempengaruhi perilaku konsumen sebagai berikut: (1) Faktor budaya. Faktor-faktor budaya meliputi: peranan kebudayaan dan kelas sosial (2) Faktor Pribadi, dari setiap konsumen akan mempengaruhi juga keputusan pembelian produk oleh konsumen tersebut. Faktor pribadi meliputi usia dan siklus hidup, pekerjaan, kondisi ekonomi, gaya hidup serta kepribadian dan konsep diri. (3) Faktor psikologis, ada empat faktor yang mempengaruhi konsumen dalam pengambilan keputusan pembelian akan sebuah hidup, yaitu persepsi, belajar, kepercayaan dan sikap, dan motiovasi.

Menurut Asma (2005) dalam rangka terciptanya kepuasan konsumen, perusahaan akan berusaha untuk mengetahui: (1) minat yang mendasari konsumen membeli produk mereka; (2) proses pengambilan keputusan pembelian produk tersebut; dan (3) penilaian (persepsi) para konsumen terhadap produk perusahaan jika dibandingkan dengan produk pesaing. Dengan memahami ketiga hal tersebut akan memungkinkan perusahaan untuk dapat memilih metode dan media komunikasi yang tepat dan sesuai dengan pasar sasarannya dan mempunyai pedoman untuk menetapkan strategi pelayanan, saluran distribusi, bersaing dan pengembangan produk di masa yang akan datang. Namun demikian perlu disadari bahwa kepuasan konsumen tidak semata-mata berasal dari baiknya kualitas produk, tetapi juga dipengaruhi oleh faktor lain seperti pelayanan pada saat dan sesudah pembelian, cara pembayaran, tersedianya spare part dan lain-lain. Tingkat hubungan antara perilaku konsumen dengan keputusan pembelian termasuk dalam kategori yang kuat atau searah, karena perilaku konsumen memiliki hasil yang positif sehingga memberikan dampak yang positif pada keputusan pembelian (Saputri, 2016).

Tujuan dari penelitian ini adalah:

1. Untuk menganalisis perbedaan preferensi konsumen dalam membeli daging broiler di pasar tradisional kota Manado

2. Untuk menganalisis sikap konsumen terhadap berbagai atribut daging broiler di pasar tradisional kota Manado. 
METODE PENELITIAN

\section{Tempat dan Waktu Penelitian}

Penelitian ini dilakukan di pasar Pinasungkulan Karombasan kota Manado pada bulan Februari 2019.

\section{Jenis dan Sumber Data}

Jenis data yang digunakan dalam penelitian ini adalah:

1. Data Primer, merupakan data yang didapat dari sumber pertama baik dari individu atau perseorangan seperti hasil dari wawancara atau hasil pengisian kuosioner yang biasa dilakukan oleh peneliti.

2. Data Sekunder, merupakan data penelitian yang diperoleh peneliti secara tidak langsung melalui media perantara. Dalam penelitian ini data sekunder diperoleh dari BPS (Badan Pusat Statistik) kota Manado.

\section{Teknik Pengumpulan Data}

Pengumpulan data dalam penelitian ini dilakukan dengan beberapa metode survey dengan wawancara yang menggunakan daftar pertanyaan yang sudah disediakan (kuosioner).

\section{Teknik PenentuanSampel}

Populasi dalam penelitian ini adalah seluruh konsumen daging broiler. Responden dalam penelitian ini adalah konsumen yang membeli daging broiler di pasar Pinasungkulan Karombasan kota Manado yang bersedia untuk diwawancarai. Penentuan sampel dalam penelitian ini menggunakan teknik accidental sampling (teknik sampling kebetulan). Accidental sampling (teknik sampling kebetulan) adalah teknik penentuan sampel berdasarkan kebetulan, yaitu siapa saja yang secara kebetulan/incidental bertemu dengan peneliti dapat digunakan sebagai sampel, bila pandangan orang yang kebetulan ditemui itu cocok sebagai responden.

Jumlah sampel yang diambil dalam penelitian ini adalah 50 responden, karena jumlah konsumen tidak teridentifikasi maka jumlah sampel ditetapkan sebanyak 50 responden. Menurut Santoso et al. (2002) jumlah sampel yang dianjurkan antara 50 100 responden. Kuisioner dijalankan dan wawancara dilakukan di pasar Pinasungkulan Karombasan kota Manado, kepada konsumen yang merupakan pengambil keputusan dalam melakukan pembelian daging broiler yang mewakili rumah tangga.

\section{MetodeAnalisis}

Analisis data yang digunakan dalam penelitian ini ada 2 jenis yaitu: analisis Chi-Square dan analisis Multiatribut Fishbein.

1. Chi-Square

Chi-Square digunakan untuk mengetahui preferensi konsumen terhadap daging broiler. Teknik dari tes chi square adalah Teknik analisis yang digunakan untuk menentukan perbedaan frekuensi observasi dengan frekuensi ekspektasi atau frekuensi 
harapan suatu kategori tertentu yang cara menentukan standart penilaian (scoring) dihasilkan. Rumus dasar perhitungan ini dengan skala likert. Skala likert berhubungan adalah (Setiadi, 2003)

$$
x^{2}=\sum_{i=1}^{k}\left[\frac{(f 0-f e)^{2}}{f e}\right] \text { dimana: } f e=\frac{R i x C i}{\sum R i}
$$

Keterangan:

$\mathrm{x}^{2}$ : chi square

fo: frekuensi yang diamati

fe: frekuensi yang diharapkan

i...k: kategori atribut dalamvariabel

Ri: jumlah baris ke-1

Ci: jumlah kolom ke-1

$\Sigma$ Ri: $\Sigma$ pengamatan

\section{Multiatribut Fishbein}

Menurut Prasetijo dan Ihalauw (2005), model multiatribut fishbein mengidentifikasi tiga faktor utama yang mempengaruhi sikap.

Rumus Multiatribut Fishbein:

$$
A_{0}=\sum_{i=1}^{n} b i . e i
$$

Keterangan:

$A_{0}$ : Sikap Konsumen terhadap objek

bi: tingkat keyakinan konsumen bahwa objek memiliki atribut tertentu (atribut ke-i)

$\mathrm{e}_{\mathrm{i}}$ :dimensi evaluative konsumen terhadap variabel ke-i yang dimiliki objek.

Untuk analisis Multiatribut Fishbein, langkahlangkah yang dilakukan:

1. Menentukan penilaian kepercayaan terhadap atribut daging broiler (bi) dengan dengan pernyataan tentang sikap responden terhadap sesuatu, adalah:

3 : baik/penting

2 : agak baik/agakpenting

1 : tidak baik/tidakpenting

2. Menentukan evaluasi mengenai atribut (ei) dengan menentukan standart penilaian (scoring) dengan menggunakan skala likert, kemudian skor masing-masing atribut dikalikan dengan frekuensi jawaban responden dan dibagi dengan jumlah responden untuk mengetahui nilai evaluasi konsumen terhadap atribut daging broiler.

\section{Definisi Variabel}

Variabel yang diamati dalam penelitian ini sebagai berikut:1) warna daging broiler 2) warnakulit daging broiler 3) kekenyalan kulit daging broiler 4) aroma daging broiler 5) bobot daging broiler 6) sikap konsumen.

\section{HASIL DAN PEMBAHASAN}

\section{Preferensi Konsumen terhadap Atribut-} Atribut Daging Broiler

Preferensi responden terhadap daging broiler merupakan pilihan suka atau tidak suka oleh seseorang terhadap produk pilihan daging broiler yang dikonsumsi. Pilihan tersebut berbeda antara responden satu dengan yang 
lain. Preferensi responden terhadap daging broiler di pasar Pinasungkulan Karombasan kota Manado dapat dianalisis menggunakan analisis Chi Square. Preferensi responden dalam membeli daging broiler di pasar Pinasungkulan Karombasan kota Manado dapat diketahui dari responden yang memilih atribut-atribut dari daging broiler yang diteliti dimana atribut tersebut adalah warna daging, warna kulit, kekenyalan kulit, aroma daging segar dan bobot daging. Dari hasil analisis $C h i$ Square dapat diketahui bahwa preferensi responden terhadap daging broiler di pasar Pinasungkulan Karombasan kota Manado menunjukkan hasil pada Tabel 1 bahwa semua atribut yang diamati dalam penelitian ini berbeda nyata dalam taraf kepercayaan 95\% yang berarti bahwa hipotesis nol (Ho) ditolak dan hipotesis satu $\left(\mathrm{H}_{1}\right)$ diterima karena $\mathrm{X}^{2}$ hitung lebih besar dari pada $\mathrm{X}^{2}$ tabel. Artinya Preferensi responden terhadap daging broiler di pasar Pinasungkulan Karombasan kota Manado tidak sama atau terdapat perbedaan preferensi responden terhadap daging broiler.

Berdasarkan Tabel 2 diatas dapat diketahui bahwa daging broiler yang disukai oleh konsumen di pasar Pinasungkulan kota Manado adalah daging broiler yang mempunyai warna daging merah kekuningan mengkilat, hal ini sesuai dengan Yulistiani (2010) bahwa warna daging ayam yang baik adalah warna putih sampai kekuningan. Warna kulit daging broiler yang di sukai oleh konsumen adalah warna putih kekuningan, dan kekenyalan kulit daging broiler yang disukai konsumen adalah elastis, serta aroma daging yang disukai konsumen adalah aroma segar. Menurut Hajrawati et al. (2016) bahwa aroma daging yang baik adalah aroma khas daging atau tidak hamis. Dan bobot daging yang disukai oleh konsumen adalah yang berat, sesuai dengan pendapat Pratama et al. (2015) karkas tertinggi ditunjukkan oleh daging broiler $\mathrm{BB} \quad 1,4 \mathrm{~kg}$ dan yang terendahdaging broiler BB 1,3 kg.

Hasil penelitian Ismanto et al. (2010) warna karkas yang akan dipasarkan harus mempunyai (1). Warna yang terang dan terlihat cerah, (2). Kulit bersih, (3).Daging yang segar, (4). Kondisi tulang utuh, (5). Bau daging segar, (6). Daging bagian dada, dan (7).

Ukuran daging sedang. 
Tabel 1. Hasil analisis Chi Square Pada Atribut Daging Broiler

\begin{tabular}{ccccc}
\hline Variabel & $\mathbf{X}^{\mathbf{2}} \mathbf{h i t u n g}$ & $\mathbf{D f}$ & $\mathbf{X}^{\mathbf{2}}$ tabel & Keterangan \\
\hline Warnadaging & 16.880 & 3 & 7.815 & Berbeda Nyata \\
Warnakulit & 16.880 & 3 & 7.815 & Berbeda Nyata \\
Kekenyalandaging & 45.640 & 2 & 5.991 & Berbeda Nyata \\
Aroma daging & 32.280 & 1 & 3.841 & Berbeda Nyata \\
Bobotdaging & 25.720 & 2 & 5.991 & Berbeda Nyata \\
\hline
\end{tabular}

Tabel 2. Preferensi RespondenTerhadap Daging broiler di pasar Pinasungkulan Ranotana kota Manado

\begin{tabular}{cc}
\hline AtributDaging Broiler & PreferensiKonsumen \\
\hline Warnadaging & Merah kekuninganmengkilat \\
Warnakulit & Putihkekuningan \\
Kekenyalankulit & Elastis \\
Aroma daging & Segar \\
Bobotdaging & Berat \\
\hline
\end{tabular}

Keyakinan dan Evaluasi terhadap AtributAtribut Daging Broiler

Indeks sikap konsumen (Ao) didapatkan dengan mengalikan angka penilaian kepercayaan (bi) dan nilai kepentingan (ei) terhadap atribut daging broiler. Angka ini menunjukkan penilaian konsumen terhadap atribut yang melekat pada daging broiler yang meliputi warna daging, warnakulit, kekenyalankulit, aroma daging dan bobot daging.

Berdasarkan Tabel 3 dapat diketahui bahwa indeks sikap responden terhadap atribut yang dipertimbangkan dalam keputusan pembelian daging broiler berturut-turut dari yang paling tinggi sampai terendah adalah warna daging sebesar 8,352, warna kulit sebesar 8,2368, kekenyalan kulit sebesar
8,0088, aroma daging sebesar 8,232, bobot daging sebesar 7,5616. Apabila dilihat berdasarkan peringkat, semakin tinggi nilai Ao maka atribut daging broiler tersebut menduduki peringkat yang pertama yang paling dipertimbangkan oleh responden, begitu juga seterusnya. Sehingga Tabel 3 menunjukkan bahwa yang menduduki peringkat pertama adalah atribut warna daging, peringkat kedua adalah warna kulit, peringkat ketiga adalah atribut aroma daging, peringkat keempat adalah atribut kekenyalan kulit, peringkat kelima adalah atribut bobot daging. 
Tabel 3. Sikap Responden Terhadap Daging Broiler di Pasar Pinasungkulan Kota Manado

\begin{tabular}{ccccc}
\hline $\begin{array}{c}\text { Atributdaging } \\
\text { broiler }\end{array}$ & $\begin{array}{c}\text { Keyakinan } \\
\text { (bi) }\end{array}$ & $\begin{array}{c}\text { Kepentingan } \\
(\mathbf{e i})\end{array}$ & $\begin{array}{c}\text { Sikap } \\
(\mathbf{A o})\end{array}$ & Peringkat \\
\hline Warnadaging & 2,88 & 2,90 & 8,352 & I \\
Warnakulit & 2,86 & 2,88 & 8,2368 & II \\
Aroma daging & 2,80 & 2,94 & 8,232 & III \\
Kekenyalankulit & 2,84 & 2,82 & 8,0088 & IV \\
Bobotdaging & 2,72 & 2,78 & 7,5616 & V \\
\hline Jumlah & 14,1 & 14,32 & 40,3912 & \\
\hline
\end{tabular}

\section{KESIMPULAN}

Terdapat perbedaan preferensi konsumen terhadap atribut-atribut daging broiler yang dipertimbangkan konsumen, dimana atribut yang paling dipertimbangkan yaitu warna daging, warna kulit, aroma daging, kekenyalan kulit dan bobot daging.

Sikap konsumen terhadap atribut
daging broiler yang paling
dipertimbangkan dalam $\quad$ keputusan
pembelian daging broiler adalah warna
daging broiler.

\section{DAFTAR PUSTAKA}

Asma, I. 2005. Pentingnya kepuasan konsumen dan implementasi strategi pemasarannya. Jurnal Siasat Bisnis. 3(1): 1-1.

Hajrawati, M. F., Wahyuni, I. I. dan Arief. 2016. Kualitas fisik, mikrobiologis, dan organoleptik daging ayam broiler pada pasar tradisional di Bogor. Jurnal Ilmu Produksi dan Teknologi Hasil Peternakan. 4(3):386-389.
Ismanto, A. T.,Julianda dan Mursidah. 2010. Analisi ssikap dan kepuasan konsumen terhadap atribut produk karkas ayam pedaging segar di pasar tradisional kota Samarinda. Jurnal Ilmu Peternakan dan Veteriner Tropis. 8 (2): $71-82$

Majid, A. 2008. Pengertian, Konsep dan Defenisi Pemasaran. http:// majid. wordpress.com/2008/06/ 30 Pengertian Konsep Pemasaran. Posted on 30 Juni 2008. Diakses Tanggal 27 Februari 2016

Prasetijo dan J.J.Ihalauw. 2005. Perilaku Konsumen. Edisi Ke Satu. Penerbit Andi Offset. Yogyakarta.

Pratama, A., K. Suradi, R. L.Balia., H. Chairunnisa., H. A. W. Lengkey., D. S. Sutardjo., L. Suryaningsih., J. Gumilar., E. Wulandri., W. S. Putranto. 2015. Evaluasi karakteristik sifat fisik karkas ayam broiler berdasarkan bobot badan hidup. Jurnal Ilmu Ternak. 15(2):6164.

Santoso, Singgih dan F. Tjiptono. 2002. Riset Pemasaran: Konsep dan Aplikasi dengan SPSS. Elex Media Komputindo. Jakarta. 
Saputri, M. E. 2016. Pengaruh Perilaku Konsumen Terhadap Pembelian Online Produk Fashion Pada Zlora Indonesia. Jurnal Sosioteknologi. 15(2):291-297.

Setiadi, N.J, 2003. Perilaku Konsumen: Konsep dan Implikasi Untuk Strategi dan Penelitian Pemasaran. Kencana, Jakarta.

Suradi,K. 2006. Perubahan Sifat Fisik Daging Ayam Broiler Post Mortem Selama Penyimpanan Temperatur Ruang. Jurnal Ilmu Ternak. 6 (1): 23-27.

Yulistiani, R. 2010. Study of un-saughtered chicken carcass: organoleptic changes and bacterial growth pattern. Jurnal Teknologi Pertanian. 11(1):27-36.

Putranto.2015. Evaluasi karakteristik sifat fisik karkas ayam broiler berdasarkan bobot badan hidup. Jurnal Ilmu Ternak. 15(2):61-64. 